\title{
Mercury and selenium in workers previously exposed to mercury vapour at a chloralkali plant
}

\author{
Dag G Ellingsen, Roy I Holland, Yngvar Thomassen, Marit Landro-Olstad, Wolfgang Frech, \\ Helge Kjuus
}

\begin{abstract}
The concentrations of total mercury (B-Hg), inorganic mercury (B-IHg), and methyl mercury (B-MeHg) in whole blood, urinary mercury (U-Hg), and selenium in urine (U-Se) and whole blood (B-Se) were determined in 74 chloralkali workers previously exposed to $\mathbf{H g}$ vapour, and compared with 51 age matched referents. Dental amalgam state, fish consumption, and exposure related indices were studied with regard to the determined elements. A significant relation between the surface of dental amalgam and U-Hg (Pearson's $r=0.63, p<0.001)$ was found among the referents. Mean U-Se was significantly lower (p $<0.001$ ) among the subjects previously exposed to $\mathrm{Hg}(34 \cdot 1 \mathrm{nmol} / \mathrm{mmol}$ creatinine) compared with that for the referents $(42.6$ nmol/mmol creatinine). A significant negative relation between the cumulative $\mathrm{Hg}$ dose and U-Se was also found. The mechanisms and the clinical significance of these findings are not clear. No relation between current $\mathrm{U}-\mathrm{Hg}$ and previous occupational exposure to $\mathrm{Hg}$ was found among subjects in whom exposure had ceased more than one year before the study.
\end{abstract}

(British fournal of Industrial Medicine 1993;50:745-752)

Workers in the mercury $(\mathrm{Hg})$ based chloralkali industry are exposed to $\mathrm{Hg}$ vapour. Liquid $\mathrm{Hg}$ is

Department of Occupational Medicine, Telemark Central Hospital, N-3906 Porsgrunn, Norway

D G Ellingsen, H Kjuus

NIOM, Scandinavian Institute of Dental Materials, N-1344 Haslum, Norway

R I Holland

National Institute of Occupational Health, N-0033

Oslo 1, Norway

Y Thomassen

Public Dental Service, Gudbrandsdalsveien 179, N-2600 Lillehammer, Norway

M Landro-Olstad

Department of Analytical Chemistry, University of Umeå, S-901 87 Umeå, Sweden

W Frech used as a cathode in the electrolysis of brine during production of chlorine and caustic soda. Leakage and maintenance work may lead to the release of $\mathrm{Hg}$ vapour into the working atmosphere.

The release of $\mathrm{Hg}$ vapour from dental amalgam restorations has been suggested as a source of exposure,,$^{1-3}$ and several authors have reported an association between the amount of dental amalgam and urinary $\mathrm{Hg}$ concentration $(\mathrm{U}-\mathrm{Hg})^{4-7}$ A decrease in the concentration of blood and plasma $\mathrm{Hg}$ was found after removal of dental amalgam fillings. ${ }^{89}$ Some authors have suggested an association between the amount of $\mathrm{Hg}$ in the human brain and dental amalgam fillings. ${ }^{1011}$

The main source of exposure to dietary $\mathrm{Hg}$ is the consumption of fish contaminated with methyl $\mathrm{Hg}$ $(\mathrm{MeHg})$. Inorganic $\mathrm{Hg}$ ( $\mathrm{IHg}$ ) in foodstuffs is poorly absorbed in the gastrointestinal tract and it is generally assumed that the exposure is low, contributing little to the total $\mathrm{Hg}$ uptake in the general population. ${ }^{12} \mathrm{Hg}$ vapour is believed to be the predominant form of $\mathrm{Hg}$ in the atmosphere. ${ }^{12}$

The interaction between selenium (Se) and inorganic $\mathrm{Hg}$ is not completely understood. The acute nephrotoxic effect of mercuric $\mathrm{Hg}$ in rats is decreased by the simultaneous administration of $\mathrm{Se},{ }^{13}$ and it has been suggested that Se may be an effective protective agent ${ }^{14}$ against the acute toxicity of $\mathrm{Hg}^{2+}$ Several authors have found decreased urinary Se concentrations (U-Se) among subjects under ongoing exposure to inorganic $\mathrm{Hg}^{1516}$ whereas others have reported higher concentrations. ${ }^{17}$ Postmortem studies on retired $\mathrm{Hg}$ miners and dentists have shown significant amounts of $\mathrm{Hg}$ and $\mathrm{Se}$ in different tissues compared with unexposed referents several years after cessation of exposure, and a roughly 1:1 molar ratio between the elements has been found. ${ }^{18} 19$

The aim of the present investigation was to study the concentrations of different $\mathrm{Hg}$ species and $\mathrm{Se}$ in whole blood and urine, and the possible relation between previous exposure to $\mathrm{Hg}$ and these concentrations among former chloralkali workers. The roles of $\mathrm{Hg}$ exposure from dental amalgam restorations and the consumption of fish were also considered. 


\section{Material and methods}

SUBJECTS

The study was performed during 1989 as a part of a comprehensive study on possible chronic untoward health effects among chloralkali workers previously exposed to $\mathrm{Hg}$ vapour in a chloralkali plant that was shut down in 1987.

Details on study design and exposure assessment have been published separately. ${ }^{20}$ Briefly, male workers under 65 years of age with at least one year of exposure to $\mathrm{Hg}$ vapour were eligible for inclusion in the study. The referents were randomly selected among men working in a nitrate fertiliser plant in the same industrial complex as the chloralkali plant and frequency matched for age. The participation rate for the dental examination was $79 \cdot 6 \%(n=74)$ among the chloralkali workers $v 83.6 \%(n=51)$ among the referents.

The exposed subjects were on average 44.9 (range $24 \cdot 2-64 \cdot 8$ ) years old, and $58 \cdot 1 \%$ were current smokers. The mean consumption of smoking tobacco was 44 (range $0-150$ ) g/week. The mean age of the referents was $45 \cdot 8$ (range 24.3-63.7) years, and $68.6 \%$ were current smokers. Their mean consumption of smoking tobacco was 55 (range 0-250)g/week.

\section{ASSESSMENT OF EXPOSURE}

Since 1948 the workers at the plant were biologically monitored by the determination of $\mathrm{U}-\mathrm{Hg}$. A cumulative U-Hg dose (cumulative U-Hg) could thereby be calculated for each worker, based on more than $2300 \mathrm{U}-\mathrm{Hg}$ measurements performed among the exposed participants during their time of employment in the plant. The cumulative $\mathrm{U}-\mathrm{Hg}$ dose expresses the sum of the individual mean U$\mathrm{Hg}$ for each year employed. The subjects in the present study had been exposed to $\mathrm{Hg}$ vapour for on average 7.9 (range $1 \cdot 1-36 \cdot 2$ ) years, and the exposure had on average ceased 12.4 (median 8.5 , range 1-35) years before the study.

\section{METHODS}

An interview and a short clinical examination were carried out for all participants, and urine specimens from two consecutive days were collected. The first sample was a morning urine first void specimen from the day before examination. The subjects had been instructed to store the urine sample in a refrigerator. The second sample was from the morning of the examination day. The urine samples were collected and stored in NUNC polypropylene tubes $(20 \mathrm{ml})$. A blood sample was obtained from the cubital vein and stored in a tube $(10 \mathrm{ml})$ containing heparin (Venoject). The blood and urine samples were frozen and stored at $-20^{\circ} \mathrm{C}$ until analysis. As urine was sampled on two consecutive days, the mean U-Se and $\mathrm{U}-\mathrm{Hg}$ has been used in the data presentation.

\section{Dental examination}

A clinical dental examination was carried out by a dentist (MLO) in a regular dental surgery. A complete oral assessment was established for all participants. The amalgam restorations were recorded, both according to number of surfaces and by grading each restored surface with a score from 0.5 to $6 \cdot 0$, according to its size. Restorations of the occlusal, buccal, and lingual/palatinal surfaces of the molars could be assigned a score from 0.5 to 6.0 , and those of the proximal surfaces of the molars from 0.5 to $4 \cdot 0$. Restored surfaces in other teeth were scored from 0.5 to 3.0 . The scores of the proximal surfaces of the molars and premolars were adjusted according to their extensions in the apical direction, which was determined from copies of $x$ ray films. By addition of the scores for all the amalgam surfaces, the value "amalgam points" was produced as an expression of the total amalgam surfaces. Occlusal points represent the score of the occlusal surfaces.

Se in whole blood (B-Se)

B-Se was measured by electrothermal atomic absorption spectrometry. A Perkin-Elmer 5100 atomic absorption spectrophotometer equipped with a Zeeman-effect based background corrector, an HGA-600 graphite atomiser, an AS-60 automatic sampler, and a Perkin-Elmer Se electrode discharge lamp were used. Pyrolytic graphite coated tubes without platforms were used and calibration was made against human whole blood Seronorm trace element 906 (NycoMed Ltd, Oslo, Norway) with a known content of Se; Se was added to this material to cover the concentration range of $0-2 \cdot 5$ $\mu \mathrm{mol} \mathrm{Se} / 1$. After thawing, the whole blood samples were diluted 1:5 with an aqueous matrix modification solution containing $0 \cdot 25 \%$ nickel nitrate and $0 \cdot 2 \%$ triton $\mathrm{X}-100$. B-Se was measured in three replicates of $20 \mu$ l diluted whole blood specimen. The detection limit was $0.02 \mu \mathrm{mol} \mathrm{Se} / 1$ (2 SD). The accuracy and precision of the measurements were monitored by use of Seronorm trace element whole blood quality assurance materials, batches 905 and 906 . The within day variation for these samples was typically $4 \%$ and the between day variation was slightly higher (typically 5\%-6\%). The average Se concentrations found in batch 905 were $1.26(\mathrm{SD} 0.06) \mu \mathrm{mol} \mathrm{Se} / \mathrm{l}(\mathrm{n}=34)$ and in batch 9061.24 (SD 0.08) $\mu \mathrm{mol} \mathrm{Se} / 1(\mathrm{n}=33)$. The certified values were 1.23 and $1.22 \mu \mathrm{mol} \mathrm{Se} / 1$ respectively.

\section{Se in urine (U-Se)}

$\mathrm{U}-\mathrm{Se}$ was measured by hydride generation atomic absorption spectrometry. A Perkin-Elmer Model 2100 atomic absorption spectrophotometer equipped with a continuous flow hydride genera- 
tion system and a Perkin-Elmer Se electrode discharge lamp was used. The urine samples were decomposed after the International Union of Pure and Applied Chemistry recommended procedure with nitric, perchloric, and sulphuric acids, ${ }^{21}$ and each urine sample was measured from three replicate readings of 2 seconds. The detection limit of the method was $0.005 \mu \mathrm{mol} \mathrm{Se} / 1$ (2 SD). The within day and between day variations were typically $4 \%$ and $6 \%$ respectively for Seronorm trace elements human urine, batch 108 . The average concentration measured in this quality control material $(0.60$ (SD 0.03) $\mu \mathrm{mol} \mathrm{Se} / 1, \mathrm{n}=8)$ was in accordance with the value recommended by the producer $(0.62$ $\mu \mathrm{mol} \mathrm{Se} / \mathrm{l})$.

\section{$\mathrm{Hg}$ in urine $(\mathrm{U}-\mathrm{Hg})$}

$\mathrm{U}-\mathrm{Hg}$ was measured by direct $\mathrm{SnCl}_{2} / \mathrm{NaOH}$ cold vapour atomic absorption spectrometry using a batch system coupled with an LDC Model 1235 mercury monitoring system. Each urine sample was measured from two replicate $125 \mu \mathrm{l}$ injections into the reagent reservoir. The detection limit of the method was $2 \mathrm{nmol} \mathrm{Hg} / 1$ (2 SD). The accuracy and precision of the measurements were ensured with a human quality assurance urine, Seronorm trace element 108 . The within day and between day variations of this material were typically $1 \%$. The average $\mathrm{Hg}$ concentration measured in Seronorm trace element 108 (245 (SD 2) $\mathrm{nmol} \mathrm{Hg} / \mathrm{l}, \mathrm{n}=15$ ) was in accordance with the certified value of 250 $\pm 10 \mathrm{nmol} \mathrm{Hg} / \mathrm{l}$.

Total mercury in whole blood $(\mathrm{B}-\mathrm{Hg})$

B-Hg was measured after a nitric/perchloric acid digestion (maximum temperature $150^{\circ} \mathrm{C}$, Tecator digestion system 40) and dilution to volume with 3 $\mathrm{M} \mathrm{HCl}$ by the same instrumentation as used for the replicate urine. The digested blood solutions were measured from two $250 \mu \mathrm{l}$ injections into a reagent reservoir of $\mathrm{SnCl}_{2} / \mathrm{HCl}$. The detection limit of the method was $3 \mathrm{nmol} \mathrm{Hg} / \mathrm{l}(2 \mathrm{SD})$. The accuracy and precision of the measurements were ensured from Seronorm trace element human whole blood 904 and 905 . The within day and between day precision of the measurements for these materials were typically $4 \%$ and $6 \%$ respectively. The average $\mathrm{Hg}$ concentrations measured (904: 24 (SD 2) $\mathrm{nmol} \mathrm{Hg} /$, $\mathrm{n}=8,906: 75$ (SD 4) $\mathrm{nmol} \mathrm{Hg} / \mathrm{l}, \mathrm{n}=8$ ) were in accordance with the values recommended by the producer of 20 and $70 \mathrm{nmol} \mathrm{Hg} / 1$ respectively.

\section{Methyl $\mathrm{Hg}(\mathrm{B}-\mathrm{MeHg})$ and inorganic $\mathrm{Hg}(\mathrm{B}-\mathrm{IHg})$ in whole blood}

Mercury species were released by adding $0.6 \mathrm{M}$ hydrochloric acid to the blood samples, and extracted as diethylcarbamate complexes (at $\mathrm{pH} 7$ ) into toluene. After derivatisation with butyl magne- sium chloride a capillary gas chromatograph with a microwave induced plasma atomic emission detector was used for speciation of mercury. The detection limit for both $\mathrm{B}-\mathrm{IHg}$ and $\mathrm{B}-\mathrm{MeHg}$ was 0.4 $\mathrm{ng} / \mathrm{g}$, and concentrations below the detection limit were set to $0.2 \mathrm{ng} / \mathrm{g}$ in the present study. Quality control of the method was performed by comparing some of the determined $\mathrm{B}-\mathrm{MeHg}$ and $\mathrm{B}-\mathrm{IHg}$ concentrations with total $\mathrm{Hg}$ values in Seronorm trace element human blood samples 904, 905, and 906. Further details of these measurements have been published elsewhere. ${ }^{22}$

$\mathrm{U}-\mathrm{Se}$ and U-Hg were corrected for urinary dilution by the urinary creatinine concentration, which was determined by Jaffé's method.

\section{STATISTICS}

Some of the distributions of the measured $\mathrm{Hg}$ and Se concentrations were skewed. Hence, the nonparametric Mann-Whitney test was applied for group comparisons. U-Se was log transformed for the least square regression analysis, and Pearson's correlation coefficients are presented. Multiple stepwise linear regression analysis was used to study several independent variables in the same model (forward procedure, $F$ to enter $=4 \cdot 0$, tolerance level $=0.01$ ). The level of significance was set to $5 \%$ and two tailed $p$ values were calculated. The statistical calculations were performed on a personal computer with the statistical data package BMDP-PC90.

\section{Results}

The Pearson's correlation coefficient between U$\mathrm{Hg}$ of the first and that of the second day was 0.80 $(\mathrm{p}<0.001)$. The correlation was lower when $\mathrm{U}-\mathrm{Hg}$ concentrations not corrected for urinary creatinine were used $(r=0.69, \mathrm{p}<0.001)$. The between day variation was on average $35.0 \%$ (median $23.7 \%$ ) for creatinine corrected concentrations, and $45 \cdot 2 \%$ (median $27 \cdot 3 \%$ ) for uncorrected U-Hg.

Table 1 presents the results of the element measurements. The concentration of $\mathrm{B}-\mathrm{MeHg}$ was higher among the referents than among the exposed subjects, whereas no significant difference in the concentration of $\mathrm{B}-\mathrm{IHg}$ between the groups was found. The subjects exposed to $\mathrm{Hg}$ excreted on average more $\mathrm{U}-\mathrm{Hg}$ than the referents $(1.8 v 1.3$ $\mathrm{nmol} \mathrm{Hg} / \mathrm{mmol}$ creatinine). The concentration of B-Se was similar in the two groups; however, the exposed subjects excreted on average significantly less U-Se compared with the referents $(34 \cdot 1 v 42.6$ $\mathrm{nmol} / \mathrm{mmol}$ creatinine). Figure 1 shows the distribution of U-Se among the exposed subjects and the referents. It seems that the measurements among the exposed subjects are generally shifted towards lower concentrations compared with the referents. 
Table 1 Concentrations of $\mathrm{Hg}$ and $\mathrm{Se}$ in 74 exposed subjects and 51 referentst

\begin{tabular}{|c|c|c|c|}
\hline & & Mean & Median (Range) \\
\hline $\mathrm{B}-\mathrm{Hg}(\mathrm{nmol} / \mathrm{l})$ & $\mathbf{E}$ & $26 \cdot 0$ & $25 \cdot 0(12 \cdot 0-61 \cdot 0)$ \\
\hline $\mathrm{B}-\mathrm{MeHg}(\mathrm{ng} / \mathrm{g})$ & $\mathbf{E}$ & $\begin{array}{r}4.6 \\
6.3\end{array}$ & $4 \cdot 2(0.2-13.9)$ \\
\hline $\mathrm{B}-\mathrm{IHg}$ (ng/g) & $\begin{array}{l}\mathbf{R} \\
\mathbf{E} \\
\mathbf{R}\end{array}$ & $\begin{array}{l}6 \cdot 3 \\
1 \cdot 7 \\
1 \cdot 5\end{array}$ & $\begin{array}{l}5 \cdot 2(1 \cdot 4-21 \cdot 1) \\
1 \cdot 4(0 \cdot 2-5 \cdot 8) \\
1 \cdot 5(0 \cdot 2-4 \cdot 0)\end{array}$ \\
\hline U-Hg (nmol/mmol creatinine) & $\mathbf{E}$ & $1 \cdot 8$ & $1.4(0.3-6 \cdot 1)$ \\
\hline B-Se $(\mu \mathrm{mol} / 1)$ & $\mathbf{E}$ & $\begin{array}{l}1 \cdot 3 \\
1 \cdot 60 \\
1 \cdot 57\end{array}$ & $\begin{array}{l}1.2(0.3-3 \cdot 8)^{\star} \\
1.61(1.07-2 \cdot 27) \\
1.57(1.07-1.99)\end{array}$ \\
\hline U-Se (nmol/mmol creatinine) & $\mathbf{E}$ & $\begin{array}{l}34 \cdot 1 \\
42 \cdot 6\end{array}$ & $\begin{array}{l}30.5(7 \cdot 0-144 \cdot 0) \\
39 \cdot 0(23 \cdot 0-116 \cdot 0) \star \star \star\end{array}$ \\
\hline
\end{tabular}

${ }^{\star} \mathrm{p}<0.05 ;{ }^{\star \star} \mathrm{p}<0.01 ;{ }^{\star \star \star} \mathrm{p}<0.001$

+B-MeHg and B-IHg were determined for 72 exposed subjects $(E)$ and 50 referents $(\mathrm{R})$.

Table 2 shows the four indices of dental amalgam assessment and fish consumption expressed as number of fish meals each month in the two groups under study. No significant differences between the exposed subjects and the referents were found.

The strongest relation between the amount of dental amalgam and $\mathrm{U}-\mathrm{Hg}$ among the referents was found between amalgam points and $\mathrm{U}-\mathrm{Hg}$ (Pearson's $r=0.63, \mathrm{p}<0.001$ ). Figure 2 shows this relation. All amalgam surfaces, occlusal surfaces, and occlusal points correlated slightly less well with U-Hg $(r=0.60, \mathrm{p}<0.001 ; r=0.55, \mathrm{p}<$ $0.001 ; r=0.58, \mathrm{p}<0.001$ respectively). The correlation between amalgam points and $\mathrm{U}-\mathrm{Hg}$ among the subjects previously exposed to $\mathrm{Hg}$ was lower

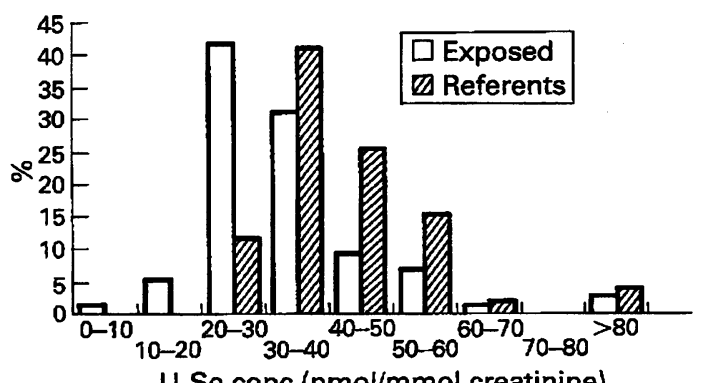

Figure 1 Distribution (in \%) of urinary Se (U-Se) among 74 subjects previously exposed to $\mathrm{Hg}$ vapour and 51 referents.

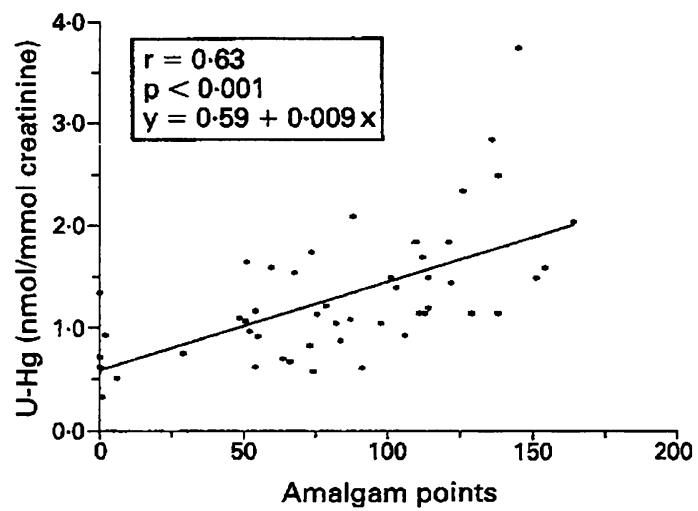

Figure 2 Relation between amalgam points and urinary $\mathrm{Hg}$ $(\mathrm{U}-\mathrm{Hg}$ ) among 51 referents.

than among the referents $(r=0.41, \mathrm{p}<0.001)$. No significant association was found between the den$\mathrm{tal}$ amalgam indices and $\mathrm{B}-\mathrm{IHg}$ or $\mathrm{B}-\mathrm{Hg}$ among the referents. Four referents with no dental amalgam fillings had on average $2.2 \mathrm{ng} / \mathrm{g}$ (range $0 \cdot 8-3 \cdot 1$ ) B-IHg. Twenty per cent of the $\mathrm{Hg}$ in whole blood among the referents was in the inorganic state. A negative association between age and amount of dental amalgam was found among both referents and exposed subjects.

The significant relation between the number of fish meals each month and $\mathrm{B}-\mathrm{Hg}(r=0.40, \mathrm{p}=$ 0.003 ) among the referents, was not found for B$\mathrm{MeHg}(r=0 \cdot 27, \mathrm{p}=0.07)$. Figure 3 shows the association among the referents between number of fish meals each week, $\mathrm{B}-\mathrm{MeHg}$, and $\mathrm{B}-\mathrm{Hg}$ respectively. Referents reporting eating less than one fish meal each week (mean 1.8 fish meals each month, range 1-2) had on average $5.2 \mathrm{ng} / \mathrm{g} \mathrm{B}-\mathrm{MeHg}$ and $22.3 \mathrm{nmol} / 1 \mathrm{~B}-\mathrm{Hg}$. Referents who fished in their leisure time $(\mathrm{n}=28)$ did not have higher $\mathrm{B}-\mathrm{Hg}$ or B-MeHg compared with the other referents.

Table 3 shows univariate relations between some of the variables. Among the referents B-Se was positively correlated with $\mathrm{B}-\mathrm{MeHg}(r=0.38, \mathrm{p}=$ $0.006)$ and negatively correlated with the current consumption of smoking tobacco $(r=-0.40, \mathrm{p}=$ $0 \cdot 004$, not shown).

Multiple stepwise linear regression analysis was used for further analysis of the concentrations of

Table 2 Dental amalgam assessment and consumption of fish among 74 exposed subjects and 51 referents

\begin{tabular}{|c|c|c|c|c|}
\hline & \multicolumn{2}{|c|}{ Exposed } & \multicolumn{2}{|c|}{ Referents } \\
\hline & Mean & Median (Range) & Mean & Median (Range) \\
\hline $\begin{array}{l}\text { No of amalgam surfaces } \\
\text { No of occlusal surfaces } \\
\text { No of amalgam points } \\
\text { No of occlusal points } \\
\text { No of fish meals each month }\end{array}$ & $\begin{array}{r}27 \cdot 1 \\
8 \cdot 8 \\
72 \cdot 8 \\
29 \cdot 8 \\
5 \cdot 5\end{array}$ & $\begin{array}{c}25 \cdot 5(0-68) \\
9 \cdot 0(0-16) \\
69 \cdot 0(0-192) \\
31 \cdot 0(0-69) \\
4 \cdot 0(0-20)\end{array}$ & $\begin{array}{r}30 \cdot 1 \\
9 \cdot 4 \\
79 \cdot 8 \\
31 \cdot 3 \\
6 \cdot 2\end{array}$ & $\begin{array}{l}31 \cdot 0(0-61) \mathrm{NS}^{\star} \\
10 \cdot 0(0-18) \mathrm{NS} \\
82 \cdot 0(0-164) \mathrm{NS} \\
30 \cdot 0(0-61) \mathrm{NS} \\
4 \cdot 0(1-20) \mathrm{NS}\end{array}$ \\
\hline
\end{tabular}

NS = Not significant. 
Table 3 Pearson's correlation coefficients for selected univariate relations among 74 exposed subjects and 51 referents†

\begin{tabular}{|c|c|c|c|c|c|c|c|}
\hline & $U-H g$ & $B-H g$ & $\mathrm{~B}-\mathrm{MeHg}$ & $B-I H g$ & $B-S e$ & $U-S e(\log )$ & Age \\
\hline $\begin{array}{l}\text { Exposed: } \\
\text { B-Hg } \\
\text { B-MeHg } \\
\text { B-IHg } \\
\text { B-Se } \\
\text { U-Se (log) } \\
\text { Age } \\
\text { Amalgam points } \\
\text { Cumulative U-Hg (log) } \\
\text { Referents: } \\
\text { B-Hg } \\
\text { B-MeHg } \\
\text { B-IHg } \\
\text { B-Se } \\
\text { U-Se (log) } \\
\text { Age } \\
\text { Amalgam points }\end{array}$ & $\begin{array}{l}0.19 \\
-0.27^{\star} \\
0.25 \\
-0.02 \\
0.13 \\
-0.36^{\star \star} \\
0.41^{\star \star \star} \\
0.14 \\
\\
0.03 \\
0.01 \\
0.22 \\
-0.05 \\
0.13 \\
-0.21 \\
0.63^{\star \star \star}\end{array}$ & $\begin{array}{l}0.37^{\star \star} \\
0.14 \\
-0.06 \\
-0.12 \\
0.08 \\
0.21 \\
0.18 \\
\\
0.75^{\star \star \star} \\
0.38^{\star \star} \\
0 \cdot 18 \\
0.09 \\
0.33^{\star} \\
-0.07\end{array}$ & $\begin{array}{c}0.04 \\
-0.20 \\
-0.30^{\star} \\
0.14 \\
-0.06 \\
-0.01\end{array}$ & $\begin{array}{r}-0.03 \\
-0.12 \\
0.01 \\
0.13 \\
0.04\end{array}$ & $\begin{aligned} & 0.43^{\star \star \star} \\
- & 0.14 \\
& 0 \\
- & 0.21\end{aligned}$ & $\begin{array}{c}-0.30^{\star} \\
0.04 \\
-0.31^{\star \star}\end{array}$ & $\begin{array}{r}-0.36^{\star \star} \\
0.46^{\star \star \star}\end{array}$ \\
\hline
\end{tabular}

${ }^{\star} \mathrm{p}<0.05 ;{ }^{\star \star} \mathrm{p}<0.01 ;{ }^{\star \star \star} \mathrm{p}<0.001$.

$\mathrm{t} \mathrm{B}-\mathrm{MeHg}$ and $\mathrm{B}-\mathrm{IHg}$ were determined for 72 exposed subjects and 50 referents.

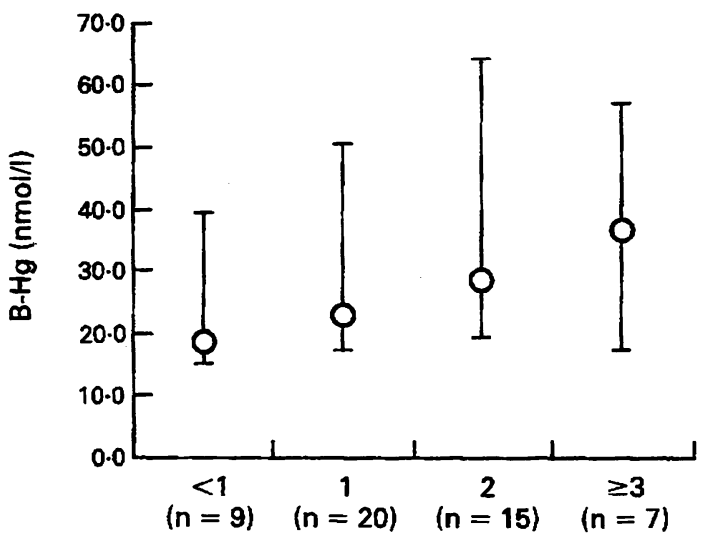

Fish meals/week

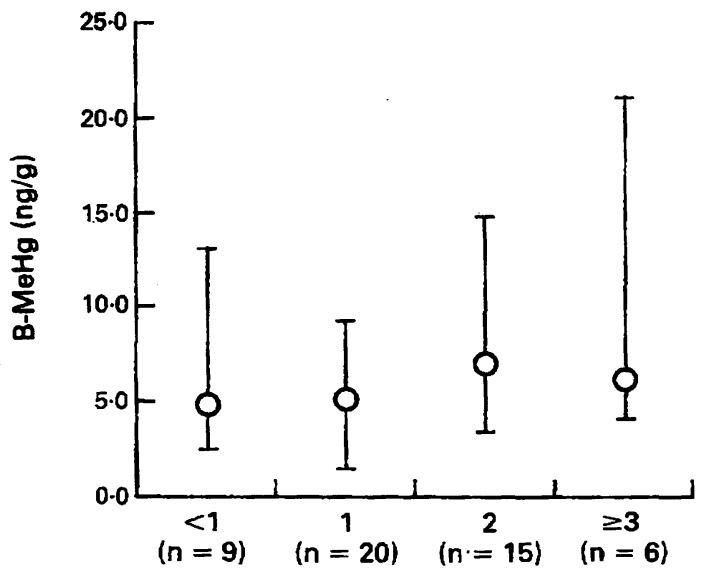

Fish meals/week

Figure 3 Relation between total blood mercury $(\mathrm{B}-\mathrm{Hg})$, methyl $\mathrm{Hg}$ in blood (B-MeHg), and number of fish meals each week among 51 referents (median and range). elements in the two groups. The model used among the referents included as independent variables; age, amalgam points, number of fish meals each month, current consumption of alcohol ( $1 /$ month), and current consumption of smoking tobacco $(\mathrm{g} / \mathrm{week})$. None of these variables contributed significantly to the models for U-Se(log), $\mathrm{B}-\mathrm{MeHg}$, or $\mathrm{B}-\mathrm{IHg}$. The amalgam points and fish meals each month were the only significant predictors for $\mathrm{U}-\mathrm{Hg}$ and $\mathrm{B}-\mathrm{Hg}$ respectively. Both current consumption of smoking tobacco and age were correlated with $\mathrm{B}-\mathrm{Se}$ (multiple $\mathrm{R}=0.50, \mathrm{p}=0.001$; $\mathrm{B}-\mathrm{Se}$ $=1.41+0.0048$ age- 0.0011 tobacco consumption). Age was not included when $\mathrm{B}-\mathrm{MeHg}$ was added to the model, but tobacco consumption remained (multiple $\mathrm{R}=0.54, \mathrm{p}<0.001 ; \mathrm{B}-\mathrm{Se}=1.52$ $+0.018 \mathrm{~B}-\mathrm{MeHg}-0.0011$ tobacco consumption) in the model. Consumption of fish meals each month was correlated with age among the referents in the present study $(r=0.40, \mathrm{p}=0.003)$.

Similarly, all exposed subjects $(n=74)$ were included in a stepwise multiple linear regression analysis of $\mathrm{B}-\mathrm{Se}$ and $\mathrm{U}-\mathrm{Se}(\mathrm{log})$, with the independent variables among the referents as well as time since cessation of $\mathrm{Hg}$ exposure and cumulative $\mathrm{U}$ $\mathrm{Hg}$. B-Se was negatively correlated with current tobacco consumption (B-Se $=1 \cdot 66-0 \cdot 0013$ tobacco consumption, multiple $R=0.29, p=0 \cdot 01)$. U$\mathrm{Se}(\log )$ was associated with time since cessation of exposure and cumulative $\mathrm{U}-\mathrm{Hg}$. (U-Se $(\mathrm{log})=2 \cdot 02-$ 0.15 cumulative $\mathrm{U}-\mathrm{Hg}(\mathrm{log})-0.004$ cessation of exposure, multiple $R=0.38, p=0.004)$. Spearman rank correlation between untransformed U-Se and cumulative $\mathrm{U}-\mathrm{Hg}$ was $r=-0.25(\mathrm{p}=0.03)$. Figure 4 shows the relation between cumulative $\mathrm{U}-\mathrm{Hg}$ and U-Se.

In a further analysis 18 subjects who were still working in the building where production had ceased more than one year before the study were 


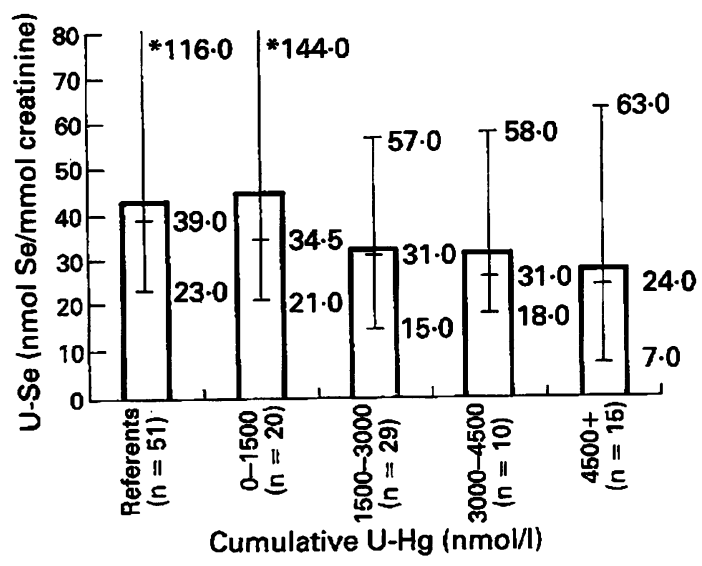

Figure 4 Relation between urinary $\mathrm{Se}(\mathrm{U}-\mathrm{Se})$ and cumulative urinary $\mathrm{Hg}$ (cumulative $U-H g$ ) among 74 subjects previously exposed to $\mathrm{Hg}$ vapour (median and range). Bars indicate the mean.

excluded. These 18 subjects had mean $\mathrm{U}-\mathrm{Hg}$ and B-Hg of 3.4 (range $1 \cdot 0-6 \cdot 1$ ) nmol/mmol creatinine and 27.0 (range $20.0-38.9$ ) nmol/1 respectively. Their mean concentration of $\mathrm{B}-\mathrm{IHg}$ was $2 \cdot 3$ (range $0 \cdot 2-5 \cdot 0) \mathrm{ng} / \mathrm{g}$. The exposure among the remaining subjects had on average ceased $16 \cdot 1$ (median 18.0 , range 1-35) years before the examination. The model included the variables used among the referents as well as time since cessation of exposure and cumulative $\mathrm{U}-\mathrm{Hg}$. Current $\mathrm{U}-\mathrm{Hg}$ concentration was correlated with amalgam points and age (U-Hg $=1.95+0.007$ amalgam points -0.02 age; multiple $R=0.65, p<0.001$ ). The number of fish meals each month and amalgam points were both positively related to $\mathrm{B}-\mathrm{Hg}$ (multiple $\mathrm{R}=0.47, \mathrm{p}=$ 0.001 ). Fish meals each month were also positively correlated with $\mathrm{B}-\mathrm{MeHg}$ (multiple $\mathrm{R}=0.37, \mathrm{p}=$ 0.006). Cumulative $\mathrm{U}-\mathrm{Hg}$ and years since cessation of exposure did not significantly contribute to any of the models.

\section{Discussion}

The comparability between the exposed subjects and referents has been discussed elsewhere. ${ }^{23}$ The participation rate was about $80 \%$ for both groups and it is not assumed that the variables studied should have influenced the participation rate in the present study. Hence, it may be assumed that the study populations are representative for a group of workers previously exposed to $\mathrm{Hg}$ vapour, and referents selected from a population of industrial workers with regard to $\mathrm{Se}$ and $\mathrm{Hg}$ state. The accuracy of the analytical procedures used for the determination of the elements in biological fluids in the present study is also regarded as acceptable.

Eighteen subjects previously exposed to $\mathrm{Hg}$ were still working in the building where production had ceased more than one year before the study. Their concentrations of $\mathrm{B}-\mathrm{Hg}$ and $\mathrm{B}-\mathrm{IHg}$ were comparable with those of the referents, indicating no current exposure. Their $\mathrm{U}-\mathrm{Hg}$, however, was higher than among the referents, which may reflect their kidney burden more than the one year postexposure. Cherian et al ${ }^{24}$ suggested that $\mathrm{U}-\mathrm{Hg}$ may be an index of renal concentration of $\mathrm{Hg}$. The remaining exposed subjects had only slightly higher $\mathrm{U}-\mathrm{Hg}$ than the referents. Among these the current B-Hg and $\mathrm{U}-\mathrm{Hg}$ were not influenced by cumulative $\mathrm{U}-\mathrm{Hg}$ or time since cessation of exposure.

Previous studies in Norway among workers occupationally unexposed to $\mathrm{Hg}$ have shown mean $\mathrm{U}-\mathrm{Se}$ and $\mathrm{U}-\mathrm{Hg}$ of $39 \mathrm{nmol} \mathrm{Se} / \mathrm{mmol}$ creatinine and $1.75 \mathrm{nmol} \mathrm{Hg} / \mathrm{mmol}$ creatinine, ${ }^{17} 1.58 \mu \mathrm{mol}$ $\mathrm{Se} / 1$ in serum, ${ }^{25}$ and $24.8 \mathrm{nmol} \mathrm{Hg} / 1$ in whole blood. ${ }^{26}$ Those results indicate that $\mathrm{U}-\mathrm{Se}, \mathrm{U}-\mathrm{Hg}$, B$\mathrm{Se}$, and $\mathrm{B}-\mathrm{Hg}$ among the referents in the present study are comparable with concentrations found in previous Norwegian studies.

The participants delivered morning urine samples from two consecutive days, and a substantial variation was found for $\mathrm{U}-\mathrm{Hg}$ between the days. Correction for urinary creatinine concentration reduced the variability. Other studies have found a reduction in the variability of $\mathrm{U}-\mathrm{Hg}$ after correction for urinary dilution. ${ }^{27}{ }^{28}$ As the analytical day to day variation in measurements of $\mathrm{Hg}$ at this concentration range is of the order of $5 \%$, the calculated $35 \%$ variation between the days is presumably caused by a real day to day variation in urinary excretion; however, storage and sampling procedures may also contribute to this variation.

Several studies have shown a relation between the $\mathrm{U}-\mathrm{Hg}$ and the amount of dental amalgam fillings. ${ }^{56}$ In our present study there was a highly significant association between the amalgam points and $\mathrm{U}-\mathrm{Hg}(r=0.63)$. The correlation coefficient was lower when the total number of amalgam surfaces was used. The relations between amalgam points and $\mathrm{U}-\mathrm{Hg}$ from day 1 and day 2 were 0.57 and 0.62 respectively, indicating that the use of amalgam points and the mean individual $\mathrm{U}-\mathrm{Hg}$ is a more appropriate expression of the biological relevance of the two variables than number of amalgam surfaces and one single value of $\mathrm{U}-\mathrm{Hg}$. The observation that mechanically active surfaces have a lower correlation with $\mathrm{U}-\mathrm{Hg}$ than has total amalgam points is supported by similar observations made in another study. ${ }^{7}$ No association was found between the amalgam indices used in the present study and $\mathrm{B}-\mathrm{Hg}$ or $\mathrm{B}-\mathrm{IHg}$ among the referents; nor was there any relation between amalgam indices and B-Se or U-Se. This finding is by contrast with other studies, which have reported an association between $\mathrm{B}-\mathrm{Hg}$ and amalgam restorations. ${ }^{7}$ Other 
authors have found a poor correlation between B$\mathrm{Hg}$ and the amount of amalgam restorations. ${ }^{6}$ It may be assumed that $\mathrm{Hg}$ vapour from dental amalgams should be measured as $\mathrm{IHg}$ in whole blood. Only $20 \%$ of total blood $\mathrm{Hg}$ among the referents was in the inorganic state. It has been suggested that chewing may influence the amount of $\mathrm{Hg}$ vapour in the mouth. ${ }^{2}$ Subsequent pulmonary uptake of $\mathrm{Hg}$ vapour may influence a possible relation between $\mathrm{B}-\mathrm{IHg}$ and amalgam indices. The subjects in the present study were not instructed to avoid eating before a blood sample was taken, which may confound a possible association between amalgam restorations and $\mathrm{B}-\mathrm{IHg}$. It has been found that the removal of amalgam fillings reduces the concentration of $\mathrm{Hg}$ in whole blood and plasma. ${ }^{89}$

A significant correlation between the number of fish meals each month and $\mathrm{B}-\mathrm{Hg}$, but not $\mathrm{B}-\mathrm{MeHg}$, was found among the referents. The $\mathrm{B}-\mathrm{MeHg}$ among referents eating little fish was comparable with that among the remaining referents. One explanation may be that other sources of fish consumption exist, such as fish as sandwich fillings, which have not been recorded in the present study. Another possibility is that other sources of $\mathrm{MeHg}$ may exist-for example, meat from animals fed with fish products. The $\mathrm{B}-\mathrm{MeHg}$ is low in the reference group, indicating a low total intake of foodstuffs contaminated with $\mathrm{MeHg}$.

An association between $\mathrm{B}-\mathrm{Se}$ and $\mathrm{B}-\mathrm{MeHg}$ was found, indicating that fish products may be a common source of $\mathrm{Se}$ and $\mathrm{MeHg}$. The number of fish meals each month was not, however, significantly correlated with B-Se. Other studies have suggested a relation between the consumption of fish and the amount of Se in serum..$^{29}{ }^{30}$ Current use of smoking tobacco was negatively correlated with B-Se among both the referents and the exposed subjects. Current smokers among all participants of the study had $0.09 \mu \mathrm{mol} / 1 \mathrm{~B}-\mathrm{Se}$ less $(\mathrm{p}<0.01)$ than current non-smokers. Ellis et al ${ }^{31}$ reported lower concentrations of Se in serum and whole blood among smokers compared with non-smokers.

There was similar B-Se in the two groups but USe was lower among the exposed subjects compared with the referents. No other studies on Se in subjects previously exposed to $\mathrm{Hg}$ are known to us. Some studies have shown decreased U-Se among subjects under ongoing exposure to inorganic $\mathrm{Hg},{ }^{1516}$ and one study has shown higher U-Se among exposed workers compared with the unexposed referents. ${ }^{17}$ The present study showed a weak negative correlation between cumulative $\mathrm{U}-\mathrm{Hg}$ and U-Se. Different mechanisms of the interaction between $\mathrm{Hg}$ and $\mathrm{Se}$ have been suggested-for example, a redistribution of $\mathrm{Se}$ on exposure to $\mathrm{Hg}$, competition for common binding sites between inorganic $\mathrm{Hg}$ and $\mathrm{Se}$, and the formation of an $\mathrm{Hg}$ -
Se complex. ${ }^{32}$ Animal models may further elucidate these mechanisms in the future.

We thank Mrs Bruun and Mrs Schistad for their technical assistance, and Ms Patricia Flor for linguistic help. This study was carried out with financial support from Norsk Hydro A/S, Norway.

Requests for reprints to: Dag G Ellingsen, Department of Occupational Medicine, Telemark Central Hospital, N-3906 Porsgrunn, Norway.

1 Svare CW, Peterson LC, Reinhardt JW, et al. The effect of dental amalgams on mercury levels in expired air. $\mathcal{f}$ Dent Res 1981;60:1668-71.

2 Abraham JE, Svare CW, Frank CW. The effect of dental amalgam restorations on blood mercury levels. $₹$ Dent Res 1984;63:71-3.

3 Vimy MJ, Lorscheider FL. Intra-oral air mercury released from dental amalgam. F Dent Res 1985;64:1069-71.

4 Frykholm KO. On mercury from dental amalgam. Its toxic and allergic effects and some comments on occupational hygiene. Acta Odontol Scand 1957;22:1-108.

5 Olstad ML, Holland RI, Wandel N, Hensten Pettersen A. Correlation between amalgam restorations and mercury concentrations in urine. $f$ Dent Res 1987;66:1179-82.

6 Langworth S, Elinder CG, Göthe CJ, Vesterberg O. Biological monitoring of environmental and occupational exposure to mercury. Int Arch Occup Environ Health 1991;63:161-7.

7 Akesson I, Schütz A, Attewell R, Skerfving S, Glantz PO. Status of mercury and selenium in dental personnel: Impact of amalgam work and own fillings. Arch Environ Health 1991;46:102-9.

8 Snapp KR, Boyer DB, Peterson LC, Svare CW. The contribution of dental amalgam to mercury in blood. $f$ Dent Res 1989;68:780-5.

9 Molin M, Bergman B, Marklund SL, Schütz A, Skerfving S. Mercury, selenium, and glutathione peroxidase before and after amalgam removal in man. Acta Odontol Scand 1990;48:109-22.

10 Nylander M, Friberg L, Lind B. Mercury concentrations in the human brain and kidney in relation to exposure from dental amalgam fillings. Swed Dent $f$ 1987;11:179-87.

11 Nylander M, Friberg L, Eggelston D, Björkman L. Mercury accumulation in tissues from dental staff and controls in relation to exposure. Swed Dent $\mathcal{F} 1989 ; 13: 235-43$.

12 World Health Organisation. Environmental health criteria 101. Methylmercury. Geneva: WHO, 1990.

13 Parizek J, Ostadilova I. Protective effect of small amounts of selenite in sublimate intoxication. Experientia 1967; 23:142-3.

14 Magos L, Webb $M$. The interactions of selenium with cadmium and mercury. Crit Rev Toxicol 1980;8:1-42.

15 Hongo T, Suzuki T, Himeno S, Watanabe C, Satoh H, Shimada $Y$. Does mercury vapor exposure increase urinary selenium excretion? Ind Health 1985;23:163-5.

16 Barregård L, Thomassen Y, Schütz A, Marklund SL. Levels of selenium and antioxidative enzymes following occupational exposure to inorganic mercury. Sci Total Environ 1990;99:37-47.

17 Alexander J, Thomassen Y, Aaseth J. Increased urinary excretion of selenium among workers exposed to elemental mercury vapor. $\mathcal{F}$ Appl Toxicol 1983;3:143-5.

18 Kosta L, Byrne AR, Zelenko V. Correlation between selenium and mercury in man following exposure to inorganic mercury. Nature 1975;254:238-9.

19 Nylander M, Weiner J. Mercury and selenium concentrations and their interrelations in organs from dental staff and the general population. Br F Ind Med 1991;48:729-34.

20 Ellingsen DG, Mørland T, Andersen A, Kjuus $\mathbf{H}$. Relation between exposure related indices and neurological and neurophysiological effects in workers previously exposed to mercury vapour. Br f Ind Med 1993;50:736-44.

21 Welz B, Wolynetz MS, Verlinden M. Interlaboratory trial on the determination of selenium in lyophilized human serum, blood and urine using hydride generation atomic absorption spectrometry. Pure and Applied Chemistry 1987;59:927-36. 
22 Bulska E, Emteborg H, Baxter DC, Frech W, Ellingsen D, Thomassen Y. Speciation of mercury in human whole blood by capillary gas chromatography with a microwave-induced plasma emission detector system following complexometric extraction and butylation. Analyst 1992;117:657-63.

23 Andersen A, Ellingsen DG, Mørland T, Kjuus H. A neurological and neurophysiological study of chloralkali workers previously exposed to mercury vapour. Acta Neurol Scand 1993 (submitted).

24 Cherian MG, Hursh JB, Clarkson TW, Allen J. Radioactive mercury distribution in biological fluids and excretion in human subjects after inhalation of mercury vapour. Arch Environ Health 1978;33:109-114.

25 Ringstad J, Fønnebø V. The Tromsø heart study: Serum selenium in a low-risk population for cardiovascular disease and cancer and matched controls. Ann Clin Res 1987;19:351-4.

26 Jokstad A, Thomassen Y, Bye E, Clench-Aase J, Aaseth J. Dental amalgam and mercury. Pharmacol Toxicol 1992:70;308-13.

27 Barber TE, Wallis G. Correction of urinary mercury concen- tration by specific gravity, osmolality, and creatinine. $\mathcal{f}$ Occup Med 1986;28:354-9.

28 Wallis G, Barber T. Variability in urinary mercury excretion. $\mathcal{F}$ Occup Med 1982;24:590-5.

29 Ringstad J, Jacobsen BK, Thomassen Y. The Tromsø heart study: Relationships between the concentration of selenium in serum and risk factors for coronary heart disease. Fournal of Trace Elements and Electrolytes in Health and Disease 1987;1:27-31.

30 Thorngren $M$, Åkesson B. Effect of dietary fish on plasma selenium and its relation to haemostatic changes in healthy adults. Int f Vitam Nutr Res 1987;57:429-35.

31 Ellis N, Lloyd B, Lloyd RS, Clayton BE. Selenium and vitamin $\mathrm{E}$ in relation to risk factors for coronary heart disease. $\mathcal{F}$ Clin Pathol 1984;37:200-6.

32 Lourdes MA, Cuvin-Aralar A, Furness RW. Mercury and selenium interaction: A review. Ecotoxicol Environ Safety 1991;21:348-64.

Accepted 26 October 1992

\section{Destruction of manuscripts}

From 1 July 1985 articles submitted for publication will not be returned. Authors whose papers are rejected will be advised of the decision and the manuscripts will be kept under security for three months to deal with any inquiries and then destroyed. 